\title{
Links between stream reach hydromorphology and land cover on different spatial scales in the Adour-Garonne Basin (SW France)
}

\author{
L. Tudesque ${ }^{(1,2)}$, M. Gevrey ${ }^{(1,2)}$, S. Lek $k^{(1,2)}$ \\ Received September 14, 2010 \\ Revised January 12, 2011 \\ Accepted April 14, 2011
}

\section{ABSTRACT}

Key-words: $\quad$ We report an investigation aimed at improving the understanding of the hydromorphology, relationships between hydromorphology and land cover, and in particuland cover, spatial scale, Random Forests, stream lar aimed at identifying the spatial scale on which land cover patterns best account for the hydromorphology at a stream reach. This investigation was carried out in the Adour-Garonne basin. Several key findings emerged from the use of a new modeling procedure called "Random Forests". Firstly, we established a typology of sites showing an upstream/downstream gradient structured by geographical descriptors and catchment hydromorphological features. Secondly, we found that the relationships between hydromorphology and the different spatial scales of land cover responded to a longitudinal gradient. Upstream, no noticeable difference was observed whatever the land cover pattern considered, whereas downstream, larger scales were strongly related to the hydromorphology. Thirdly, a specific land cover effect on each hydromorphological type was seen. Along the gradient, the contribution of the land cover variables structuring the hydromorphological types decreased and become homogeneous. Fourthly, stronger correlations were established with individual hydromorphological variables using the larger scales of land cover. This paper contributes to a better understanding of landscape ecology and fits well with the European Water Framework Directive that requires long-term sustainable management. In the context of natural conditions, we advise that the catchment scale should be given high priority when connected with land cover/uses; local and riparian environments being more valuable and complementary in the case of impacted sites.

\section{RÉSUMÉ}

Relations entre l'hydromorphologie de section de cours d'eau et l'occupation du sol à différentes échelles spatiales dans le bassin Adour-Garonne (S-O France)

\begin{abstract}
Mots-clés : échelle spatiale, hydromorphologie occupation du sol,

Nous présentons les résultats d'une étude destinée à accroître la compréhension des relations entre l'hydromorphologie d'une portion de cours d'eau et l'occupation du sol, et particulièrement à identifier l'échelle spatiale pour laquelle l'emprise de l'occupation du sol est la plus déterminante. Cette étude a été conduite dans le bassin Adour-Garonne. Plusieurs résultats majeurs ont émergé suite à l'utilisation d'une technique récente de modélisation appelée « Ramdom Forests ».
\end{abstract}

(1) CNRS UPS ENFA; UMR5174 EDB (Laboratoire Évolution et Diversité Biologique), 118 route de Narbonne, 31062 Toulouse, France, tudesque@cict.fr

(2) Université de Toulouse, UPS, UMR5174 EDB, 31062 Toulouse, France 
Random

Forests,

rivière
Premièrement, nous avons mis en évidence une typologie des sites d'étude, montrant un gradient amont/aval, structurée à la fois par les descripteurs géographiques et les caractéristiques hydromorphologiques des bassins. Deuxièmement, nous avons trouvés que les relations entre l'hydromorphologie et les différentes échelles spatiales répondaient également à un gradient longitudinal. Dans les zones amont, aucune différence notables n'a été observée quelque soit le type d'occupation du sol considéré, alors qu'en aval, les larges échelles spatiales étaient plus étroitement reliées à l'hydromorphologie. Troisièmement, il a été observé un effet spécifique de l'occupation du sol sur chaque type d'hydromorphologie. Le long du gradient, la contribution des variables d'occupation du sol structurant les types d'hydromorphologie décroissait pour ensuite devenir homogène. Quatrièmement, les relations les plus fortes ont été établies entre les variables hydromorphologiques et les variables d'occupation du sol pour les échelles les plus larges. Cet article, contribuant à une meilleure compréhension de l'écologie du paysage, est en accord avec la Directive Cadre Européenne prônant une gestion durable de l'environnement. Dans le contexte de conditions naturelles, nous recommandons de prendre en compte prioritairement l'échelle du bassin versant lorsque des connexions sont établies avec l'occupation du sol; I'environnement local ou rivulaire étant complémentaire et plus pertinent dans le cadre de sites impactés.

\section{INTRODUCTION}

Analyses of river system integrity, whereby interactions between spatial patterns and ecological processes are considered, have demonstrated the importance of the context of the landscape (Hitt and Broberg, 2002) in addition to the attributes of local sites (Gergel et al., 2002). Rivers are hierarchical and show distinct patterns of variability in a range of spatial scales and in response to numerous causal factors. Information regarding the landscape in which a hydrosystem is contained is essential, with the streams being linked to, and structured by the terrestrial landscape (Vondracek et al., 2005). There has been a growing interest in improving our understanding of the influence of the landscape at various levels on ecosystem structures and function by identifying scales on which landscape indicators are most influential (Allan et al., 1997; Molnar et al., 2002). Riparian conditions and landscape uses are micro-/proximal and macro-/distal indicators of environmental disturbance, respectively (Pinto et al., 2006). Different environmental variables of streams can be expected to vary in their sensitivity to large- versus local-scale environmental factors (Allan, 2004b). Hydromorphology plays a central role among all the components acting on a river system: it especially comprises important habitat parameters for all the biota. The hydromorphological features of a river constitute a physical framework in which the biotic and abiotic interactions are organized and structured. Any change or deterioration in these conditions has a direct or indirect effect on the hydraulic conditions, and becomes an important stress factor affecting instream biota and ecological integrity. The considerable literature, dating back more than five decades, dealing with the influence of scale (Harvey, 1967; Penning-Rowsell and Townshend, 1978; Carlisle et al., 1989; Levin, 1992), and stream channel characteristics (Leopold and Wolman, 1957; Strahler, 1964; Hynes, 1975; Frissell et al., 1986; Hawkins et al., 1993) is evidence of the importance of the physical habitat as a driver of ecological responses. During the last decade the increasing use of remotely-sensed datasets and Geographic Information Systems means that studies involving multiple spatial scales linked with land cover patterns have become widespread (see Orr et al., 2008; Buffagni et al., 2009; Kail et al., 2009; Sandin, 2009; Vaughan et al., 2009).

The increasing knowledge of the interaction between various components of a river system is becoming crucial in the context of the European Union's (EU) Water Framework Directive (WFD: EC/2000/60) which requires, on the one hand, the identification of the "reference condition "of a river's status and on the other hand, the implementation of river quality assessment tools, both for abiotic and biotic components. Traditional approaches to identifying 

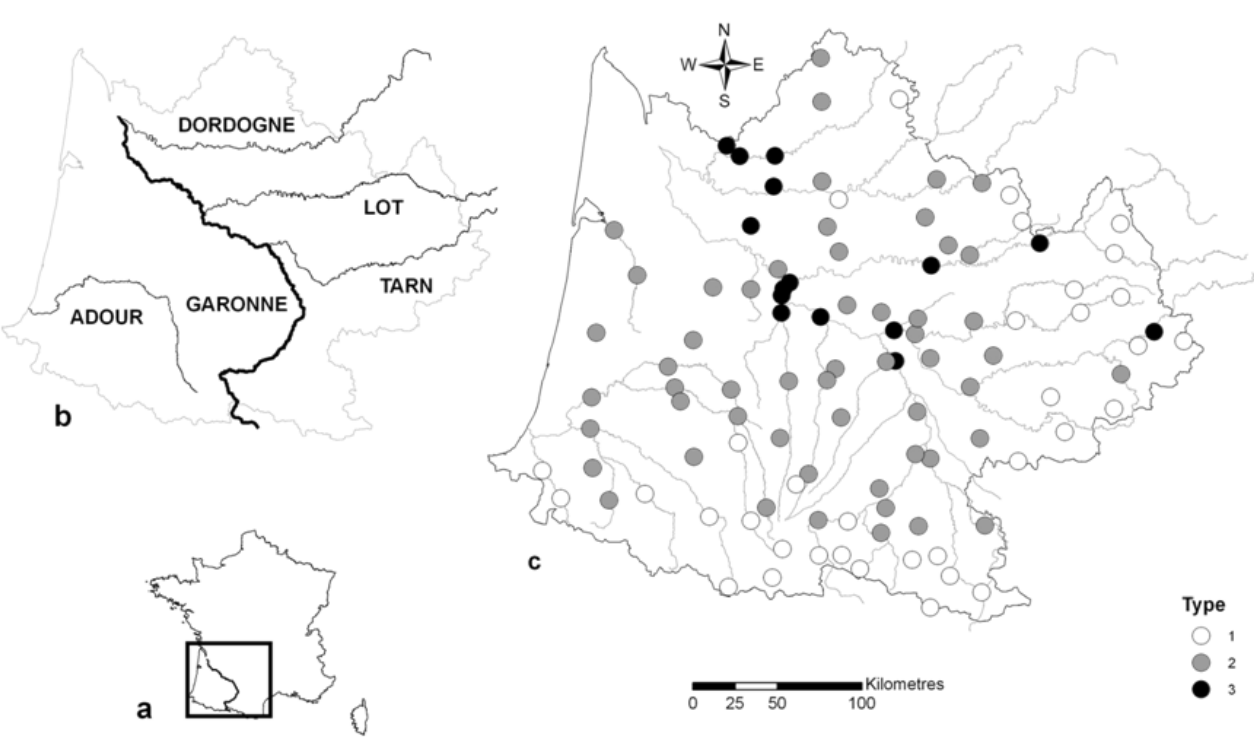

\section{Figure 1}

Study area: (a) location of the Adour-Garonne basin in South-Western France; (b) main rivers; (c) location of the 104 study sites and correspondence with their hydromorphological type.

the human impact on rivers are mainly based on water chemistry and biotic indices, but these measures are the final state resulting from the initial conditions and pollution. Investigation into the changes taking place in the land cover makes it possible to detect directly the origin of unspecified disturbances. Strong relationships between land cover and nutrient concentration or export have been observed for different parameters (Johnson et al., 1997; Gergel et al., 2002).

The aim of our study was to establish the links between local hydromorphological variables, such as geographical descriptors such as channel and bank features or flow types at the stream reach, and the land cover patterns on multi-spatial scales. By land cover patterns we mean the ratio of the different urban, agricultural and forest classes described in Corine Land Cover 2000 (European Environment Agency, Institut Français de l'Environnement - IFEN).

The study design was based on a four-stage procedure: (1) we established a typology of sampling sites from their hydromorphological features; (2) using land cover variables as predictors, we predicted the typology and determined the relevance of each spatial scale; (3) we examined the contribution of explanatory land cover variables in predicting the various hydromorphological types; and (4) we established the link between hydromorphological variables independently and explanatory land cover on different spatial scale patterns in the predictive model.

\section{MATERIALS AND METHODS}

\section{$>$ STUDY AREA}

The study was conducted at 104 sites in the Adour-Garonne Basin (Figure 1). The selection of sampling sites was made in order to overlap with the sampling sites of the national fish survey program in the Adour-Garonne area managed by the ONEMA (Office National de l'Eau et des Milieux Aquatiques), according to the implementation of the Water Framework Directive (WFD). The Adour-Garonne hydrographic network covers South-West France in the Atlantic area and groups together 6 main sub-basins. It extends over $116000 \mathrm{~km}^{2}$ from Charentes (north) and the Massif Central (east, north-east) to the Pyrenees (south), gathering $120000 \mathrm{~km}$ of watercourses including $68000 \mathrm{~km}$ of permanent rivers flowing into the Atlantic Ocean. The 
river Garonne is the main channel, running over $580 \mathrm{~km}$ from the central Pyrenees in Spain to the Gironde estuary on the Atlantic coast. Its major tributaries come from the Massif Central plateau (Dordogne, Lot and Tarn) and minor ones from the Pyrenean range (The Gaves); for more details about the features of the Adour-Garonne river networks see Poulain (2000) and Ecogea and Geodiga (2007). The Adour-Garonne watershed covers a wide range of altitudes (high mountains to plains and coastal areas) and geological substrates: calcareous, sedimentary, sandstone, crystalline and volcanic (Tison et al., 2004). From the south to the north-west, the topography and climate determine three major landscape types: the Pyrenees mountains with a pronounced relief, a vast green hilly zone of piedmont, and the valley of the Garonne River with flood zones and alluvial terraces. The oceanic influence predominates over the whole basin, but lessens to the south-east with its Mediterranean influence, dry winds and lower rainfall. The geographical features, involving climate, geology and relief, are summarized in the concept of a hydroecoregion. This typology of aquatic ecosystems results from the implementation of the WFD. The studied basin covers 6 hydroecoregions (Wasson et al., 2001), from the south to the north: Pyrenees (headwaters of the left bank tributaries of the Garonne), Côteaux aquitains (main floodplain), and limestone Causses; to the east: Grands Causses and Massif Central (headwaters of the right bank tributaries of the Garonne) and in the west the coastal streams of Les Landes.

\section{> DATASET OF HYDROMORPHOLOGICAL FEATURES}

According to the terms and definitions of the European Water Framework Directive hydromorphology is: "the physical characteristics of the shape, the boundaries and the content of a water body". This term combines two elements: (1) "hydro", mainly described by the water velocity and flow units; and (2) "morphology", which combines local (width, bank features) and regional physical descriptors (geography, catchment structure).

The majority of the hydromorphological features of river sites were collected by field observation according to the protocol derived from the methodologies of the River Habitat Survey, RHS (Environment Agency, 2003) and the "SEQ-Physique - Système d'Evaluation de la Qualité physique des eaux"- (Agence de l'eau Rhin-Meuse, 2005, 2006). The field survey sheet gives detailed information on a selection of 79 variables distributed in 9 categories. However, for pertinent statistical analyses we made a selection of 27 variables distributed in 5 categories (Table I) as many attributes could not be registered at each site.

A 100 - to 500-meter length of river channel, judged to be homogeneous with regards to the substratum composition, the flow, and the surrounding environment, was chosen at each site. Each selected stretch (the length depending on the river width) was examined once during the summer with stable hydrological conditions and low turbidity. At each location, the field sheets were completed by two observers as follows: (i) the data related to channel features, water velocity and river width were average values of measurements made at randomly selected locations; (ii) the flow types were identified by the water surface disturbance and the flow speed according to the RHS (River Habitat Survey), and the classifications of Malavoi and Souchon (2002) and Delacoste et al. (1995). The percentages of each flow type and plant cover of the riverbed were estimated according to the field protocol described in Hürlimann et al. (1999); (iii) the bank erosion and the angle along the length of the reach were directly described as a percentage of the total length of both banks. The catchment hydromorphological variables were calculated using the Geographic Information System tool with a Digital Elevation Model, even though the geographical descriptors were extracted from classical cartography on a $1 / 25000$ scale.

\section{> LAND COVER DATASET}

A Geographic Information System (ESRI ArcView GIS 9.2 software) was used to determine the watershed boundaries and to extract the relative percentages of land cover (CORINE land 
Table I

Categories, names, data types and methodology of acquisition of the 27 hydromorphological variables recorded for each sampling site.

\begin{tabular}{|l|l|l|}
\hline Categories & Variables & Data type and acquisition \\
\hline Geographical descriptives & Slope & Numerical - cartography \\
& Altitude & Numerical - cartography \\
& Distance from source & Numerical - cartography \\
& Relief - Valley & Binary - field observation \\
Channel features and & Relief - Plain & Binary - field observation \\
flow types & Width & Numerical - field observation \\
& Shading & Percentage - field observation \\
& Water velocity & Numerical - field observation \\
& Chute & Percentage - field observation \\
& Chaotic flow & Percentage - field observation \\
& Rippled (riffle) & Percentage - field observation \\
& Laminar with disturbed surface & Percentage - field observation \\
& Laminar without disturbed surface & Percentage - field observation \\
& No perceptible flow & Percentage - field observation \\
& Stable cliffs & Percentage - field observation \\
& Eroding cliffs & Percentage - field observation \\
& Gentle profile & Percentage - field observation \\
Channel vegetation types & Steep profile & Percentage - field observation \\
& Filamentous algae & Percentage - field observation \\
& Mosses & Percentage - field observation \\
& Lotic hydrophytes & Percentage - field observation \\
& Lentic hydrophytes & Percentage - field observation \\
& Catchment area & Numerical - GIS \\
& Perimeter & Numerical - GIS \\
& Linear of watercourses & Numerical - GIS \\
& Drainage & Numerical - GIS \\
& Index of compactness & Numerical - GIS \\
\hline
\end{tabular}

cover 2000, Institut Français de l'Environnement - IFEN) on different spatial scales. CORINE land cover 2000 (CLC2000) is an update for the reference year 2000 of the first database, which was finalized in the early 1990 s as part of the European Commission program to COoRdinate INformation on the Environment (CORINE - http://www.eea.europa.eu/). The CORINE land cover database provides a pan-European inventory of biophysical land cover and constitutes a key database for integrated environmental assessment. CORINE land cover nomenclature is a hierarchical system with three levels using 5 headings for the first level, 15 for the second level and 44 for the third one (details of these categories are given in the appendix).

For the characterization of the land cover on multi-spatial scales, we used 5 patterns (commonly presented in the literature) covering 1) the whole basin (B), 2) the whole basin stream network buffer (HB), 3 ) a sub-basin, delimited upstream by the closer main tributary (Z), 4) the sub-basin stream network buffer $(\mathrm{HZ})$ and 5) a local $(\mathrm{L})$ sample reach (Table II). For the two stream network scales (HB, HZ), the land cover was extracted with a $200-\mathrm{m}$ buffer $(100 \mathrm{~m}$ on both sides of the river), and the local sample reach ( $L$ ) extended over a radius of $500 \mathrm{~m}$ from the sampling site. Land cover data collected on the reach scale reflected local conditions, and data collected over the entire stream upstream region (riparian corridor or entire catchment) could reflect regional conditions (Allan et al., 1997).

We considered both the second (CLC2) and third levels (CLC3) of CORINE land cover (see appendix). Thus, the land cover extraction on 5 spatial scales combined with two levels of CORINE land cover built up 10 different databases characterizing the land cover at each study site. 
Table II

Summary of the five spatial scale patterns considered. Correspondence between the codification, the spatial scales and the amplitude of scales.

\begin{tabular}{|l|c|c|}
\hline Code & Spatial patterns & Amplitude of scale patterns \\
\hline $\mathbf{B}$ & Basin & Large scale \\
$\mathbf{H B}$ & Stream buffer & \\
$\mathbf{Z}$ & Sub-basin & Meso-scale \\
$\mathbf{H Z}$ & Stream buffer & Local scale \\
$\mathbf{L}$ & $500 \mathrm{~m}$ & . \\
\hline
\end{tabular}

\section{> MODELING PROCEDURES}

Our methodology encompasses analyses on multiple spatial scales, ranging from the whole basin catchment to the local scale, and including different longitudinal buffer extents. Statistical analyses, especially Random Forests, RF (Breiman, 2001a, 2001b), have been used to determine the explanatory power of the landscape parameters on different spatial scales. A Random Forests analysis consists of a compilation of classification or regression trees (e.g. 500 trees in a single Random Forests analysis), and is empirically proven to be better than its individual members (Hamza and Larocque, 2005). RF models have been used with high accuracy of prediction and explanation for ecological data (see, e.g., Cutler et al., 2007; De'ath, 2007; Peters et al., 2007).

Preliminarily, to obtain a normal distribution, hydromorphological data were log-transformed. Then, in order to reduce variations in the data scale between variables, and to enhance the informative signal, data were standardized.

Firstly, to determine the hydromorphological similarities between study sites, the 104 sites were classified through a hierarchical cluster analysis using Ward's linkage method with the Euclidean distance measure. The Mean Split Silhouette (MSS) criterion (Pollard and van der Laan, 2002) and the Multiple Response Permutation Procedure (MRPP) (Mielke and Berry, 1976) were used to validate the clustering relevance.These steps led to a definition of the typology of the study sites called "observed type" (type) of hydromorphology.

Secondly, to predict the hydromorphology types from the different scales of land cover data, we used a newly developed machine learning technique called "Random Forests" (RF). It is a statistical classification method which has been mainly used in bio-informatics, genetics and remote sensing, and is relatively unknown in ecology (Cutler et al., 2007; Peters et al., 2007). The RF technique, introduced by Breiman (2001a, 2001b), is an effective tool in prediction, combining tree predictors. Unlike classical regression techniques for which the relationship between input and output variables should be pre-specified, RF avoids exclusive dependence on data models. The RF model is grown with a randomized subset of predictors which generate a large number of Classification And Regression Trees (CART). To model a new object from input variables, each tree of the forest produces a predictive value, and then the outputs of all the trees are aggregated to produce one final prediction. For classification, the class chosen is the one having the most "votes" over all trees, and for regression, the final value is the average value of the individual tree predictions. This technique allows the analyst to view the importance of the predictor variables.

Predicted types with RF (class of prediction) were compared with observation types (class of observation) resulting from the hierarchical cluster analysis. The correct classification rate (good prediction) was obtained from the confusion matrix that identified the true or false position cases predicted, with the predictor variables being the land cover classes on multiple spatial scales. Prediction accuracy was evaluated by computing the percentage of correctly classified predictions versus observations, called the prediction score or performance.

Thirdly, the relative importance of predictor variables for each model by the calculation of the mean decrease accuracy was also evaluated. When a tree is grown using a bootstrap sample from the original data, about one-third of the cases are left out of the bootstrap sample and not used in the construction; they are called oob (out-of-bag) data. This out-of-bag data is used 


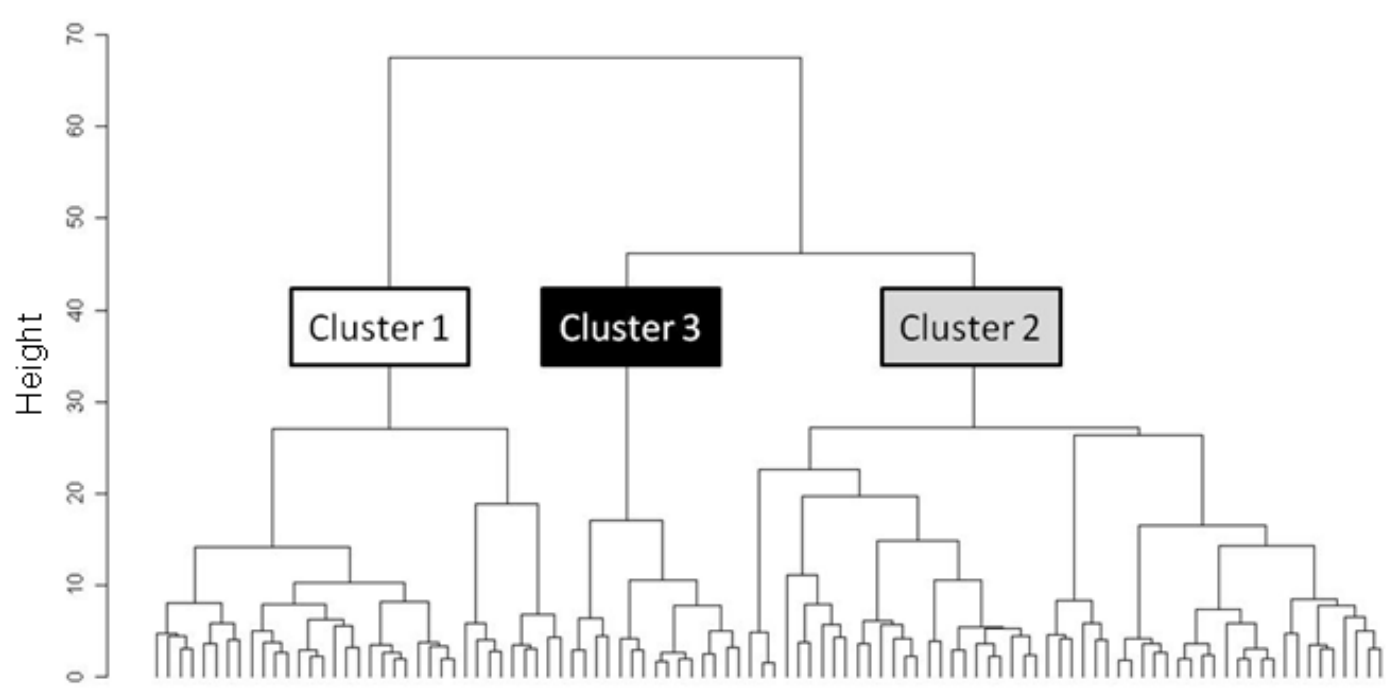

Figure 2

Classification of the sampling sites based on the similarity of spatial hydromorphological data. Dendrogram obtained with hierarchical cluster analysis using Ward's linkage method with the Euclidean distance measure.

to get a running unbiased estimate of the classification error as trees are added to the forest. The mean decrease accuracy is obtained by calculating the difference between the prediction accuracy of the oob portion and the prediction accuracy of the oob data after permuting each predictor variable. The decrease in accuracy for each predictor is averaged and standardized across all trees. This importance measure is given either for the global prediction or for each class. The relative decrease in prediction accuracy, when a predictor variable is permuted, is related to its importance in the classification (Carlisle et al., 2009).

Finally, we predicted the hydromorphological variables independently with RF. The different spatial scales were tested in order to study the effect of the scale on the prediction of each variable. The accuracy of these models was tested classically using the correlation between the predicted value and the observed one.

The number of trees to grow in our RF models was set at 500 and the number of randomly selected variables to split the nodes was set at the square root of the number of predictor variables. "Leave-one-out" cross validation was applied to evaluate the generalization capacity of the Random Forests model. The dataset was effectively too small to be divided into two parts and the leave-one-out procedure was therefore more appropriate (Kohavi, 1995). Moreover, this process provides a nearly unbiased estimate of the model's accuracy (Olden and Jackson, 2000).

The RF regression algorithm was implemented by the Random Forests $R$ package (Liaw and Wiener, 2002) performed using the R environment (R Development Core Team 2004, Vienna, Austria).

\section{RESULTS}

\section{> HYDROMORPHOLOGY-BASED TYPOLOGY}

From the hierarchical cluster analysis (using Ward's linkage) classifying the stations according to their hydromorphological similarities, we could divide the 104 sites into 3 main groups (Figure 2). On the one hand, the MSS identified that the optimal level of the classification tree where the clusters were more homogeneous is 3 . On the other hand, the MRPP analysis tests if the differences between the clusters are significant; and it is the case with $p<0.001$. The sites belonging to each cluster (hydromorphology type) are presented on the map, showing 

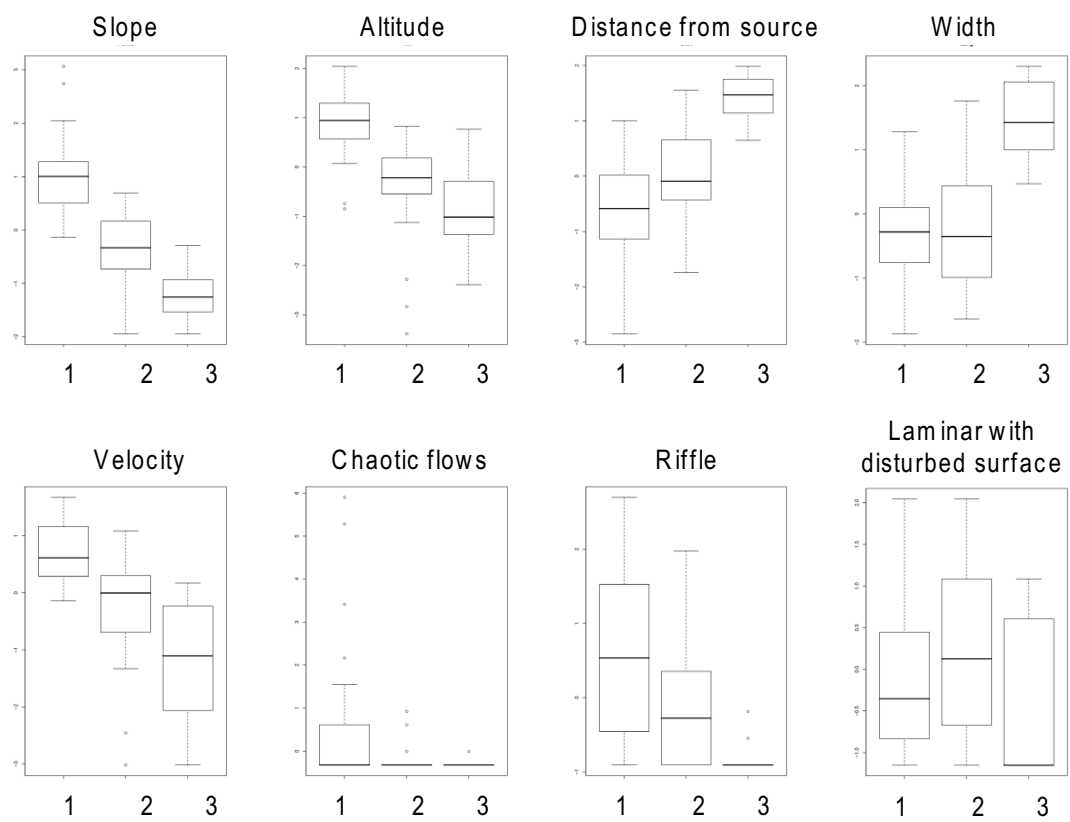

Lam inar with
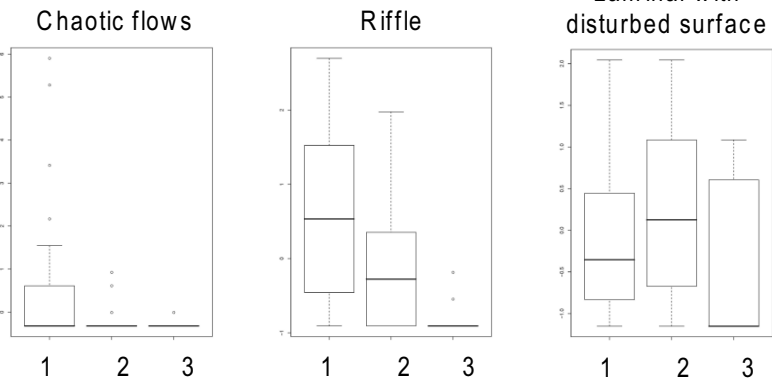

Lam inar without
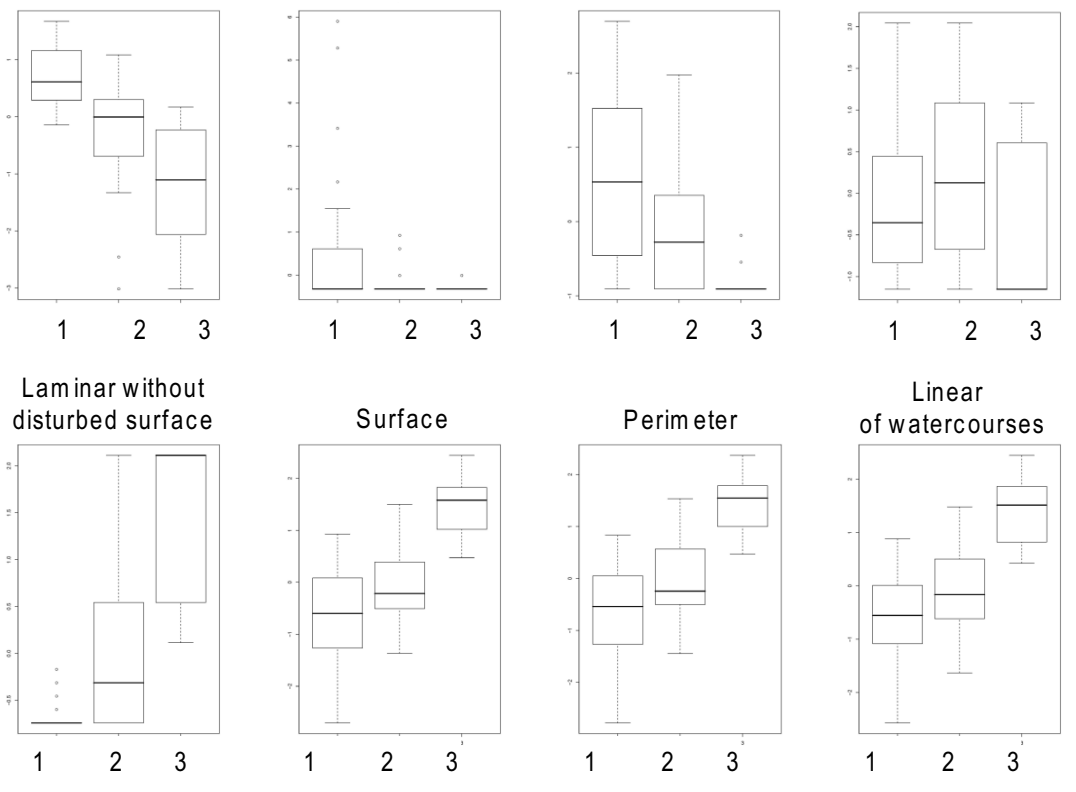

Filam entous algae

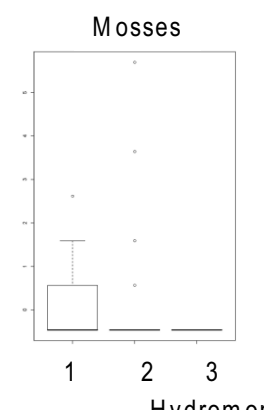

Lotic hydrophytes
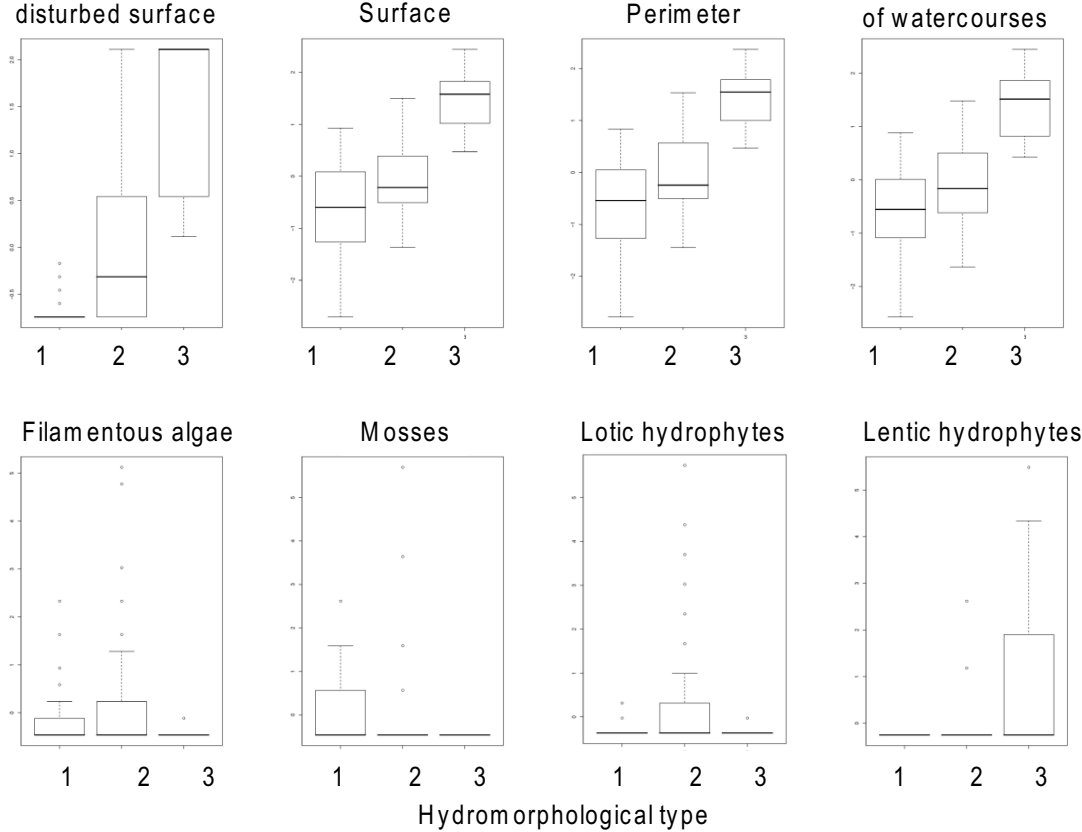

\section{Figure 3}

Box plots showing the distribution of 16 main relevant hydromorphological variables in each observed hydromorphological type $(1,2 \& 3)$. The box plots indicate the range of variables: the horizontal line in the box shows the median, and the bottom and top of the box show the 25th and 75th percentiles, respectively. The vertical lines represent 1.5 times the interquartile range of the data and the points represent the outliers.

an apparent geographical distribution (Figure 1c). According to the spatial distribution of the clusters and their hydromorphological features summarized with the box plot in Figure 3, we could draw up a typology of the sites as follows:

(i) Hydromorphology type 1 comprised the sites at high altitude located in the Pyrenean Mountains and in the foothills of the Pyrenees and Massif Central (eastern border of the 


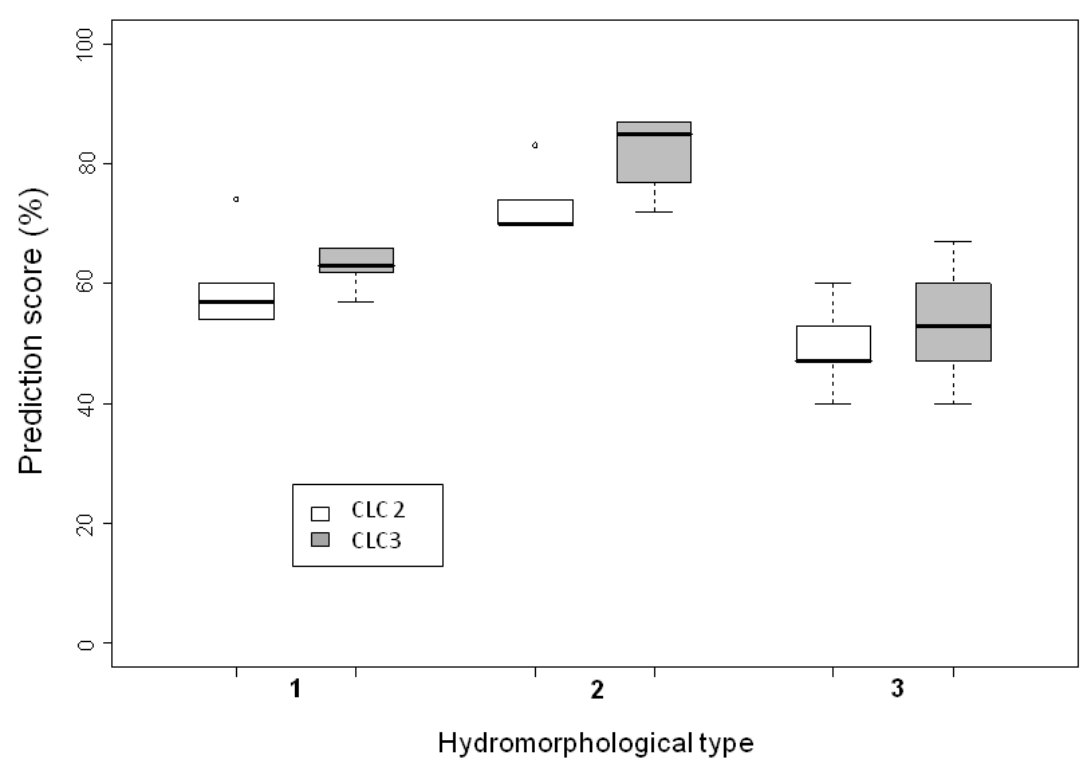

\section{Figure 4}

Distribution of the prediction performance for each hydromorphological type for the two levels of CORINE land cover nomenclature (CLC $2 \&$ \&LC 3). The box plots indicate the range of performance among the spatial scales: the horizontal line in the box shows the median, and the bottom and top of the box show the 25th and 75th percentiles, respectively. The vertical lines represent 1.5 times the interquartile range of the data and the points represent the outliers.

Adour-Garonne basin). These sites had the highest slope and altitude with high current velocity and turbulent morphodynamic units;

(ii) Hydromorphology type 2 comes in between the two other clusters. It was composed of a majority of sites located in the Aquitaine and Garonne piedmonts and plains (western and central parts).

(iii) Hydromorphology type 3, with only 15 sites, corresponded to the larger river sites mainly located in the north-western border (Dordogne basin) and in the "Nord Aquitain" plain (downstream of the river Garonne) with a large width, low velocity and smooth morphodynamic units.

In Figure 1c, three dots do not seem to match with the typology described above. These "anomalies" are two black dots (type 3) located in the eastern border of the basin, and one white dot (type 1) in the northern part. On the one hand, the two dots are sites in large rivers in an urban area (Tarn) or with meanders (Lot) in a large valley with slow flow. On the other hand, the white dot (type 1), located in lowland, is a little tributary of the river Dordogne in a wooded hilly area. Despite their marginal geographical distribution, these three sites fit well with the types described above.

\section{> PREDICTION OF HYDROMORPHOLOGICAL TYPES}

The box plots in Figure 4, illustrating the distribution of the prediction within and between the clusters for the two CORINE land cover levels, indicate that CLC3 is better at predicting hydromorphological types. On the basis of the results in Figure 4, the focus was put on CLC3. Table III summarizes the scores of Random Forests and the standard deviation (SD) of the prediction score for the different spatial scales of each type. The Random Forests modeling method used to predict the typology in 3 clusters shows moderate to good predictive performance, with a scaling of prediction ranging between $40 \%$ and $87 \%$. The model pointed out the presence of non-linear relationships between predictors and dependent variables with on average $66 \%$ of prediction performance. The SD values show that according to each type, 


\section{Table III}

Scores (in percentage) of hydromorphological type predictions based on Random Forests for the 5 spatial scales of land cover patterns for CORINE nomenclature CLC3. Mean and standard deviation (SD) per type.

\begin{tabular}{|c|c|c|c|c|}
\hline Land cover pattern & Type 1 & Type 2 & Type 3 & Mean per LC pattern \\
\hline CLC3_B & 63 & 87 & 60 & 70 \\
\hline CLC3_HB & 57 & 87 & 67 & 70 \\
\hline CLC3_Z & 66 & 85 & 47 & 66 \\
\hline CLC3_HZ & 62 & 77 & 40 & 60 \\
\hline CLC3_L & 66 & 72 & 53 & 64 \\
\hline Mean CLC3 & 63 & 82 & 53 & \\
\hline $\mathrm{Sd} C L C 3$ & 3.5 & 6.7 & 10.5 & \\
\hline \multicolumn{5}{|c|}{ GLOBAL MEAN = 66} \\
\hline
\end{tabular}
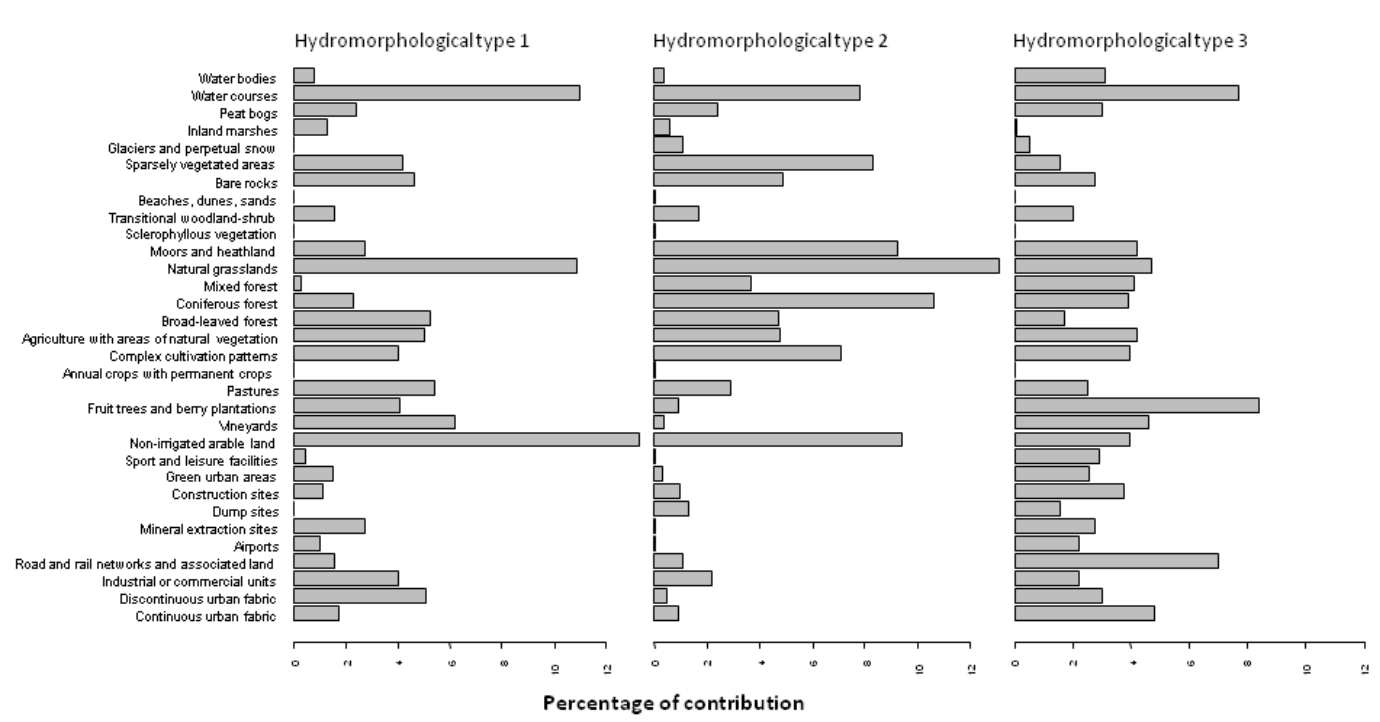

\section{Figure 5}

Relative contribution (\%) of explanatory variables for the 3 hydromorphological types. The most relevant scale patterns of land cover are averaged for each type.

the spatial scale of the land cover pattern has a variable effect on the cluster performance prediction. The SD is lowest for cluster 1 and highest for cluster 3 . The low variability in RF scores and the low value of the SD for type 1 mean that there is no significant difference in predicting this type whatever the spatial scale of land cover taken into account. The local or the large spatial scales do not affect the prediction sensitivity of the hydromorphological typology of a stream reach grouping upstream mountain sites. The highest value of the SD for the type 3 results has a clear effect on the success of the prediction according to the variation in the spatial scale of land cover pattern as a predictor. The best predictions are obtained with the larger scales: the whole basin and the whole basin stream network buffer patterns. In the case of the type 2, the SD has a median position. The effect of the land cover scale variation is more moderate than in type 3 but clearer than in type 1 . A local scale seems to be the less relevant pattern, whereas a large scale gives more accurate predictions.

\section{> CONTRIBUTION OF EXPLANATORY LAND COVER VARIABLES IN PREDICTING HYDROMORPHOLOGICAL TYPES}

The relative importance of variables derived from Random Forests highlights the contribution of land cover predictors in the hydromorphological type prediction. The results are presented in Figure 5 for the 3 hydromorphological types. According to the previous results, the relative 


\section{Table IV}

Percentage of land cover classes versus percentage of contribution for each hydromorphological type. The land cover classes have been gathered into the 4 main categories based on CLC1 nomenclature (the classes wetlands and water bodies are grouped together).

\begin{tabular}{|l|c|c|c|c|c|c|}
\cline { 2 - 7 } \multicolumn{1}{c|}{} & \multicolumn{9}{c|}{ Hydromorphological } \\
\cline { 2 - 7 } \multicolumn{1}{c|}{} & \multicolumn{2}{c|}{ Type 1 } & \multicolumn{2}{c|}{ Type 2 } & \multicolumn{2}{c|}{ Type 3 } \\
\cline { 2 - 7 } & \% land cover & \% contribution & \% land cover & \% contribution & \% land cover & \% contribution \\
\hline Artificial areas & 1.1 & 18.0 & 1.5 & 25.4 & 56.0 & 33.0 \\
Agricultural areas & 34.1 & 37.0 & 55.2 & 57.0 & 41.9 & 27.6 \\
Forest & 64.5 & 30.0 & 43.2 & 10.2 & 0.4 & 13.9 \\
Wetlands/water & 0.3 & 15.0 & 0.2 & & & \\
bodies & & & & & \\
\hline
\end{tabular}

importance was averaged for each variable using a selection of the more relevant land cover scale patterns assigned to each type: for type 1 the five scale patterns were averaged, patterns B, HB, Z \& HZ for type 2 and B \& HB for type 3. As shown in Figure 5, "non-irrigated arable land", "water courses" and "natural grasslands" are the three main land cover classes explaining $35 \%$ of type 1 . Only 2 classes of land cover are above $10 \%$ of contribution to explain type 2: "natural grasslands" in common with type 1 and "coniferous forest". In type 3 , the maximum contribution of the explanatory variables is less than $10 \%$. The three most important land cover classes are the "fruit tree plantation", "water courses" and "artificial surfaces". The "water courses" class is the only one showing a similar importance in the 3 types. The high homogeneity for both net river and drainage density throughout the Adour-Garonne basin accounts for the similar importance of the land cover class "water courses" in the 3 types. Besides, the variables "drainage" and "linear of watercourses" were not considered as pertinent, owing to their invariance, when classifying the sites into three types.

In order to point out the importance of the land cover classes in the prediction of hydromorphological type, we draw a parallel between what is observed in the field (land cover) on the most commonly used spatial scale (whole basin) and its theoretical contribution to explaining the hydromorphological types (RF results). To do that, and to facilitate and make the analysis more relevant, we grouped the classes of land cover into only 4 major classes: artificial surfaces, agricultural areas, forests and natural areas and wetlands/ water bodies (similar to label level 1 of CORINE land cover). The results presented in Table IV point to the dominance of forest cover upstream (type 1), whereas agricultural areas become dominant downstream (types 2 and 3). Although the percentage of artificial areas remained under $2 \%$, there was an obvious increase in this class from types 1 to 3 . The most significant element emerging from this analysis is the large shift between the representation of the land cover in the basins and the percentage of contribution in the prediction of the types. This fact is particularly important with respect to the class "artificial areas" which, whatever the considered types, represented less than $2 \%$ of surface, whereas its contribution ranged from $7.5 \%$ to $33 \%$. This is also the case for the "water bodies" with very low surface areas ( $<0.5 \%$ of the areas) which represented 10 to $14 \%$ of the contribution. In the case of the "agricultural areas", the contribution was maximal in type 1, and for the class "forest", the highest contribution was in type 2.

\section{> PERFORMANCE MEASURES TO PREDICT HYDROMORPHOLOGICAL VARIABLES FROM DIFFERENT EXPLANATORY LAND COVER PATTERNS}

In order to investigate any relationships between the hydromorphological variables and multispatial scale of land cover patterns, we used the performance measures between the observed hydromorphology and the predicted values (Table V). Only 17 variables were considered, as for some hydromorphological variables, e.g. geographic description or catchment hydromorphology, the correlation with the land cover variable is nonsense. The results show the ability of the models using the larger scales of land cover pattern to predict hydromorphological data, as 9 variables have performances superior to 0.30 . On the local scale, only 


\section{Table V}

Performance measures of the hydromorphological variable predictive model using different land cover pattern classes as predictors (CLC3B, CLC3HB, CLC3Z, CLC3HZ and CLC3L): correlation coefficient between measured hydromorphological variables and the values predicted using different land cover patterns. Gray scale indicates values greater than 0.5 and 0.3 .

\begin{tabular}{|l|c|c|c|c|c|}
\hline \multirow{2}{*}{ Hydromorphological variables } & \multicolumn{5}{|c|}{ Land cover patterns } \\
\cline { 2 - 6 } Width & CLC3B & CLC3HB & CLC3Z & CLC3HZ & CLC3L \\
Water velocity & 0.87 & 0.87 & 0.73 & 0.75 & 0.66 \\
Chaotic flow & 0.45 & 0.58 & 0.45 & 0.44 & 0.31 \\
Cascade & 0.29 & 0.44 & 0.31 & 0.28 & -0.01 \\
Riffle & 0.33 & 0.34 & 0.13 & 0.17 & 0.21 \\
Smooth surface with current & 0.32 & 0.21 & 0.34 & 0.35 & 0.29 \\
Smooth surface without current & 0.41 & 0.41 & 0.22 & 0.22 & 0.10 \\
Lentic channel & 0.42 & 0.48 & 0.36 & 0.35 & 0.26 \\
Stable bank & 0.04 & 0.02 & -0.04 & -0.01 & -0.07 \\
Unstable bank & 0.03 & -0.10 & -0.03 & -0.06 & -0.04 \\
Gentle bank profile & 0.03 & -0.12 & -0.03 & -0.05 & -0.04 \\
Steep bank profile & 0.38 & 0.38 & 0.31 & 0.29 & 0.13 \\
Filamentous algae & 0.38 & 0.35 & 0.29 & 0.27 & 0.16 \\
Bryophytes & 0.07 & 0.04 & 0.00 & 0.01 & 0.01 \\
Lotic hydrophytes & 0.45 & 0.37 & 0.20 & 0.22 & 0.07 \\
Lentic hydrophytes & 0.12 & 0.13 & -0.05 & -0.06 & -0.11 \\
Helophytes & 0.26 & 0.25 & 0.30 & 0.25 & 0.12 \\
\end{tabular}

two variables have high correlation coefficients. The highest correlation coefficients were observed for "width" and "water velocity" and can be quite well predicted from all scales of land cover patterns.

\section{DISCUSSION}

\section{> HYDROMORPHOLOGY-BASED TYPOLOGY}

Following the examples of hydromorphological studies in Central Europe (Sandin and Verdonschot, 2006), the first environmental variability that we obtained was along a mountain/lowland gradient where large-scale factors are predominant (first dichotomy in the dendrogram between cluster 1 and clusters 2-3). The second partition between clusters 2 and 3 defines a gradient of "mid-sized lowland streams" to "large-sized rivers" on the slow-flowing stream bottom without a distinct valley. In the background of these results, the channel vegetation type plays a secondary role in the definition of the typology classification and represents distinctive components of each type. Types 1 to 3 are represented, respectively, by (i) mosses, (ii) filamentous algae and lotic hydrophytes, and (iii) lentic hydrophytes. Local variables such as bank structure or other variables of catchment hydromorphology (drainage, index of compactness) seem to have a smaller effect on defining the typology. These results underline the hierarchical overlapping of hydromorphological variables, where geographical features (slope, altitude, distance from source, width) and catchment hydromorphology parameters (perimeter, catchment area) emerge as key factors in modeling hydromorphological typology. These factors concerning a large area reveal the use of large-scale variables to analyze the typological aspect (Feld, 2004).

\section{> PREDICTION OF HYDROMORPHOLOGICAL TYPES}

The prediction of hydromorphological types with the RF highlights three significant outcomes in terms of the relevance of the predictions according to (i) the nomenclature level of CORINE land cover, (ii) the type, and (iii) the scale of land cover pattern. Thus, firstly, the reduction in 
the number of predictors (CORINE land cover classes) seems to be unfavorable for prediction with Random Forests, whereas the CORINE nomenclature level 3 (CLC3) proved to be more suitable. As described in Goldstein et al. (2007), "more refined classifications of land cover would probably improve attempts to relate land use to stream ecosystems". Secondly, the Random Forests prediction scores are clearly influenced by the number of sites in each type. Type 2 (54 sites), which gave the best performance measures, gathered the majority of the study sites, whereas type 3 (15 sites), which has the lowest number of study sites, had the lowest score, and Type 1 (35 sites) comes in between the two other groups. Moreover, it is established that the relations between the hydromorphological typology of a stream reach and the consideration of different spatial scales of land cover react to a longitudinal upstream/downstream gradient. In the head watercourse mountain sites (type 1), the land cover patterns have the same effect on the hydromorphological features whatever the spatial scale considered: no significant differences are identified. Downstream, in the flood plain (type 2), some perceptible differences appear; in particular, local CORINE land cover has less influence. At the other end of the gradient, large scales are predominant and are strongly correlated to the settings of the hydromorphology.

In the literature the results are frequently contradictory and the role of near-stream vs. larger spatial scales can be difficult to separate (Allan, 2004a). While some studies concluded that there are stronger relations with large spatial scales (Roth et al., 1996), others, on the contrary, promote closer relationships with smaller scales (Lammert and Allan, 1999; Allan, 2004b), Vondracek et al. (2005) and Kail et al. (2009) reported that both local and catchment scales are significantly related to hydromorphology. Lammert and Allan (1999) suggested that these different outcomes might be explained by differences in study design.

In the case of the two lateral scales (basin and buffer) the results do not show any clear differences between them.

\section{> CONTRIBUTION OF EXPLANATORY LAND COVER VARIABLES IN PREDICTING HYDROMORPHOLOGICAL TYPES}

The analysis of the contribution of explanatory land cover variables for hydromorphological type prediction shows that despite their equal richness for the three types (32 land cover classes), the distribution of the importance of the land cover class patterns appears to be characteristic for each of them. This feature denotes a specific land cover effect on each type. These results underline an upstream/downstream gradient with a gradual decrease in the contribution of the explanatory variables. Upstream, in type 1, only a few land cover classes have a high degree of contribution. Thus, on the one hand, in the headwater, the hydromorphological typology of the sites seems to be closely linked with well-defined and specific land cover classes. On the other hand, the relative contribution of land cover classes tends to be progressively less indicative and more homogeneous in cluster 2 and even more so in cluster 3. Downstream, in the flood plain, the link between the hydromorphological typology and the land cover classes appears to be a "non-specific" relationship. In addition, the parallel drawn between the percentage of land cover and the percentage of contribution indicates that whatever the hydromorphological type, the dominant class of land cover is not the most contributive in predicting the hydromorphological type. We can interpret this effect as follows: the main hydromorphological types are described by a homogeneous frame, built with a set of major and structuring classes. On the other hand, the minor land cover classes appear to be the more sensitive. These marginal classes react like pertinent sensors to detect changes taking place in the different hydromorphological units.

\section{> PERFORMANCE MEASURES TO PREDICT HYDROMORPHOLOGICAL VARIABLES FROM DIFFERENT EXPLANATORY LAND COVER PATTERNS}

The correlation between the observed values and the predicted hydromorphological variables with the land cover pattern was highest with the two larger-scale patterns of land cover (whole 
basin and stream whole basin network buffer). The local and median extents (sub-catchment and stream sub-basin network buffer - meso-scale) appear to be irrelevant. Secondly, the correlations established with the physical data ("width" and "water velocity") are quite good: the highest correlation is with the "width". In the context of these results, we underline the decrease in the correlation coefficient from the large scale to the local pattern that highlights the sensitivity and the accuracy of the analysis. Except for the "lentic canal" variable, all the morphodynamic units are rather well linked with the large scale of land cover patterns. Concerning the "bank structure" attributes, only the data about the bank profile gives good correlations; the stability of banks being less related whatever the land cover scale pattern. It is known that the stability of banks is strongly dependent on surrounding conditions; therefore this expected point is not recorded. This results from the study design where mainly natural and non-physically modified river reaches were sampled. On the contrary, the variable "profile" is registered more clearly and appears to be a reliable parameter for large-scale patterns of land cover. The aquatic vegetation performs poorly: only "mosses" and "lentic hydrophytes" correlated with the land cover. The variable "aquatic vegetation" is not directly a variable of hydromorphology but it is closely related. The results concerning the aquatic vegetation are in accordance with those obtained with respect to the physical variables and the morphological descriptors. The mosses are indicative of running water in a cascade or riffle, although helophytes are adapted to more lentic areas, for which correlation is less strong. Thus, we found biological components and physical features to be indirectly correlated.

\section{$>$ CONCLUSION}

Rivers have their own internal structure composed of a variety of hydrodynamic units, making them internally heterogeneous landscapes (Wiens, 2002). The structural and functional internal architecture that characterizes a hydrosystem is integrated, and reflects a broader terrestrial environmental context; the challenge therefore is to define the relevant limits of this influence (Vaughan et al., 2009). From this perspective, the goal of the present study was not to establish the connection between each single land cover class with each specific hydromorphological variable by setting out cause-effect relationships (one-to-one relation), but to globally consider the closest link between a set of local hydromorphological descriptors and the variation in spatial scale of land cover.

Based on hydromorphological features, the classification of the 104 sites distributed all over the Adour-Garonne basin made it possible to define a typology. This typology clearly shows an upstream/downstream gradient where the geographic descriptors (large-scale factors) are the structuring elements. This expected result needs to be compared with the predictive typologies produced by Random Forests with the different scales of land cover patterns. Attempts to identify the spatial scale of the land cover which correlated best with the hydromorphological reach features indicated that catchment-wide land use (whole basin or stream buffer) seems to be the most significant; in agreement with Allan et al. (1997). Land use predictors diminished to insignificance as the spatial scale decreased. Whatever the distribution of stream reaches in the headwater or in the floodplain, large-scale land use was shown to be a strong predictor of hydromorphological settings. Somewhat surprising was the finding that the local scale was not the most significant or the indisputable predictor unit even though intuitively stream reach physical characteristics would be expected to be under the direct influence of adjacent land use. Concurrently, the explanatory land cover variables showed the same gradient with a gradual decrease in their contribution. Upstream, the contributions of the land cover class were well established, and progressively they become homogeneous.

The prediction performance established between hydromophological features and the land cover pattern showed a better relationship with the larger scale. Nevertheless, discrepancy between the different spatial scales remained weak. The results led to a trend showing that the catchment scale seems to be of primary importance. Smaller scales appeared to be in the background but in any case are of importance. These findings, putting in the foreground the larger scale, must be considered in a restricted framework where the selected studied 
sites are not affected by any physical impairment and the land cover resolution is based on CORINE Land Cover GIS processing. $n$ the context of natural conditions the results appear to be useful for examining the origins of the connection between land use and the local river hydromorphological dynamics. In particular, it is demonstrated that a zooming in on land use does not provide a better or more relevant connection with the components of the habitat of a local river reach. The land cover database is necessary for the analysis of the causes and consequences of natural and artificial processes, impact assessment, identification of trends and the contribution to the maintenance of the ecological balance and its consideration in decision-making processes. Nevertheless, much attention must be given to land cover resolution. Our study design dealt with spatial scale but did not take into account change in land cover resolution. A further investigation would be to modify land cover resolution in parallel with the spatial scale, in other words: CORINE Land Cover resolution for the catchment scale and a thinner field observation resolution for the local scale (i.e. presence of narrow-vegetated buffer strips not detected by CORINE Land Cover). While few studies have focused on the relationships between hydromorphology and land cover on multi-spatial scales, our investigation carried out in South-Western France could have useful applications for local policies and for agents in charge of the surveillance program of the aquatic environment. Understanding how land cover structure on multiple spatial scales is linked to hydromorphological features could facilitate the development of effective conservation strategies and tools. This paper fits particularly well with the implementation of the European Water Framework Directive that requires long-term sustainable management based on a high level of protection of the aquatic environment and the prevention of its deterioration. Hydromorphology assessment forms an integral part of the WFD survey and monitoring program. The typology required by the WFD is mainly aimed at the definition of specific condition references. In France, the national WFD river typology approach is based on the Hydroecoregion (Wasson et al., 2002) delimited by geology, relief and climate features. Within these homogeneous geographical entities, streams and rivers exhibit common characteristics. A clear distinction between natural variability and human impact is necessary (Verdonschot and Nijboer, 2004). In the specific context of natural conditions exempt from notable physical impairment our study provides underpinning outcomes. As key findings in the framework of the assessment of natural conditions, we advise that the larger extent, i.e. the catchment scale, should be given high priority when connected with a set of land cover/uses. If the larger condition appears to be a greater value for natural conditions; local and riparian environments could supply valuable information in the case of impacted sites. Divergence between the strength of the relationships Hydromorphology /Land Cover on the catchment scale and Hydromorphology /Land Cover on the local scale could be interpreted as a sensor of hydromorphological impairment.

\section{ACKNOWLEDGEMENTS}

The authors are very grateful for the funding support under the EU FP6 Integrated Project "Euro-limpacs" (Integrated Project to evaluate the Impacts of Global Change on European Freshwater Ecosystems - contract number GOCE-CT-2003-505540). We thank John Woodley and Elanor France for reading our MS and for the correction of the English.

\section{REFERENCES}

Agence de l'Eau Rhin-Meuse, 2005. Qualité du milieu physique du Muhlbach de Gertsheim - campagne 2004-2005. 24 p. + annexes.

Agence de l'Eau Rhin-Meuse, 2006. Outil d'évaluation de la qualité du milieu physique. Metz.

Allan J.D., 2004a. Influence of land use and landscape setting on the ecological status of rivers. Limnetica, 23, 187-198.

Allan J.D., 2004b. Landscape and riverscapes: The influence of land use in stream ecosystems. Ann. Rev. Ecol Evol. S., 35, 257-284. 
Allan J.D., Erickson D.L. and Fay J., 1997. The influence of catchment land use on stream integrity across multiple spatial scales. Freshwater Biol., 37, 149-161.

Buffagni A., Casalegno C. and Erba S., 2009. Hydromorphology and land use at different spatial scales: expectations in a changing climate scenario for medium-sized rivers of the Western Italian Alps. Fund. Appl. Limnol., 174, 7-25.

Breiman L., 2001a. Random Forests. Mach. Learn., 45, 5-32.

Breiman L., 2001b. Statistical modeling: The two cultures. Stat. Sci., 16, 199-215.

Carlisle D.W., Skalski J.R., Batker J.E., Thomas J.M. and Cullinan V.I., 1989. Determination of ecological scale. Landscape Ecol., 2, 203-213.

Carlisle D.M., Falcone J. and Meador M.R., 2009. Predicting the biological conditions of streams: use of geospatial indicators of natural and anthropogenic characteristics of watersheds. Environ. Monit. Assess., 151, 143-160.

Cutler D.R., Edwards T.C.K., Beard H, Cutler A. and Hess K.T., 2007. Random forests for classification in ecology source. Ecology, 88, 2783-2792.

De'ath, G., 2007. Boosted trees for ecological modeling and prediction. Ecology, 88, 243-251.

Delacoste M., Baran P., Lek S. and Lascaux J.M., 1995. Classification et clé de détermination des faciès d'écoulement en rivières de montagne. Bull. Fr. Pêche Piscic., 337-339, 149-156.

Ecogea and Geodiga, 2007. Recensement des cours d'eau et des milieux aquatiques à "caratère patrimonial" sur le basin Adour-Garonne. Cours d'eau remarquables. Rapport final novembre 2007. Agence de l'Eau Adour-Garonne. 12 p. + annexes.

Environment Agency, 2003. River Habitat Survey in Britain and Ireland. Field survey guidance manual: version 2003. $136 \mathrm{p}$.

European Community. Directive 2000/60/EC of the European Parliament and of the Council of 23 October 2000 establishing a framework for Community action in the field of water policy. Official journal of the European Communities 2000; L 327, 22.12.2000: 1-72.

Feld C.K., 2004. Identification and measure of hydromorphological degradation in Central European lowland streams. Hydrobiologia, 516, 69-90.

Frissell C.A., Liss W.J., Warren C.E. and Hurley M.D., 1986. A hierarchical framework for stream habitat classification: viewing streams in a watershed context. Environ. Manage. 10199-214.

Gergel S.E., Turner M.G., Miller J.R., Melack J.M. and Stanley E.H., 2002. Landscape indicators of human impacts to riverine systems. Aquat. Sci., 64,118-128.

Goldstein R.M., Carlisle D.M., Meador M.R. and Short T.M., 2007. Can basin land use effects on physical characteristics of streams be determined at broad geographic scale? Environ. Monit. Assess., 130, 495-510.

Hamza M. and Larocque D., 2005. An empirical comparison of ensemble methods based on classification trees. J. Stat. Comput. Sim., 75, 629-643.

Harvey D.W., 1967. Pattern, process, and the scale problem in geographical research. Trans. Inst. Br. Geogr., 45, 71-78.

Hawkins C.J., Kerschner J.L., Bisson P.A., Bryant M.D., Decker L.M., Gregory S.V., McCoullough D.A., Overton C.K., Reeves G.H., Steedman R.J. and Young M.K., 1993. A hierarchical approach to classifying stream habitat features. Fisheries 18, 3-11.

Hitt N.P. and Broberg L.E., 2002. A river integrity assessment for the western Montana. Final report.

Hürlimann J., Elber F. and Niederberg K., 1999. Use of algae for monitoring rivers: an overview of the current situation and recent developments in Switzerland. In: Prygiel J., Witton B.A., Bukowska J. (eds.), Use of Algae for monitoring rivers III, Agence de I'Eau Artois- Picardie, Douai, France, 39-56.

Hynes H.B.N., 1975. The stream and its valley. Verhandlungen der Internationalen Vereinigung für Theoretische und Angewandte. Limnologie 19, 1-15.

Johnson L.B., Richards C., Host G.E. and Arthur J.W., 1997. Landscape influences on water chemistry in Midwestern stream ecosystems. Freshwater Biol., 37, 193-208.

Kail J., Jahnig S.C. and Hering D., 2009. Relation between floodplain land use and river hydromorphology on different spatial scales - a case study from two lower-mountain catchments in Germany. Fund. Appl. Limnol., 174, 63-73. 
Kohavi R., 1995. A study of cross-validation and bootstrap for estimation and model selection. Proceedings of the Fourteenth International Joint Conference on Artificial Intelligence. Morgan Kaufmann Publishers Inc., 1137-1143.

Lammert M. and Allan J.D., 1999. Assessing biotic integrity of streams: Effects of scale in measuring the influence of land use/cover on habitat structure on fish and macroinvertebrates. Environ. Manage. 23, 257-270.

Leopold L.B. and Wolman M.G., 1957. River Patterns: Braided, Meandering and Straight. U.S. Geological Survey Professional Paper 282-B, 51 p.

Levin S., 1992. The problem of pattern and scale in ecology. Ecology, 73 1943-1967.

Liaw A. and Wiener M., 2002. Classification and regression by Random Forests. R News. 2/3:18-22. [online] URL http://CRAN.R-project.org/doc/Rnews/. Little EL. 1971. Atlas of United States trees.

Malavoi J.R. and Souchon Y., 2002. Description standardisée des principaux faciès d'écoulement observables en rivière : clé de détermination qualitative et mesures physiques. Notes techniques. Bull. Fr. Pêche Piscic., 365, 366, 357-372.

Mielke P.W. and Berry K.L., 1976. Multiresponse permutation procedures for a priori classifications. Communications in Statistics, A5, 1409-1424.

Molnar P., Burlando P. and W. Ruf, 2002. Integrated catchment assessment of riverine landscape dynamics. Aquat. Sci., 64, 129-140.

Olden J.D. and Jackson D.A., 2000. Torturing data for the sake of generality: how valid are our regression models? Ecoscience 7, 501-510.

Orr H.G., Large A.R.G., Newson M.D. and Walsh C.L., 2008. A predictive typology for characterising hydromorphology. Geomorphology, 100, 32-40.

Penning-Rowsell E.C. and Townshend J.R.G., 1978. The influence of scale on the factors affecting stream channel slope. Trans. Inst. Br. Geogr., New Series 3, 395-415.

Peters J., De Baets B., Verhoest N.E.C., Samson R., Degroeve S., De Becker P. and Huybrechts W., 2007. Random Forests as a tool for ecohydrological distribution modeling. Ecol. Model., 304-318.

Pinto B.C.T., Araujo F.G. and Hughes R.M., 2006. Effects of landscape and riparian condition on a fish index of biotic integrity in a large southeastern Brazil river. Hydrobiologia, 556, 69-83.

Pollard K. and van der Laan M., 2002. A method to identify significant clusters in gene expression data. In Sixth World Multiconference on Systemics, Cybernetics and Informatics, 318-325.

Poulain P., 2000. Le volet "poissons migrateurs du SDAGE Adour-Garonne". Bull. Fr. Pêche Piscic., 357/358: 311-322.

R Development Core Team. R, 2004. A language and environment for statistical computing. R Foundation for Statistical Computing, Vienna, Austria: R Foundation for Statistical Computing. http//www.R-project.org.

Roth N.E., Allan J.D. and Erickson D.E., 1996. Landscape influences on stream biotic integrity assessed at multiple spatial scales. Landscape Ecol., 11, 141-156.

Sandin L., 2009. The relationship between land-use, hydromorphology and river biota at different spatial and temporal scales: a synthesis of seven case studies. Fund. Appl. Limnol., 174, 1-5.

Sandin L. and Verdonschot P., 2006. Stream and river typologies-major results and conclusion from the STAR project. Hydrobiologia, 566, 33-37.

Strahler A.N., 1964. Quantitative geomorphology of drainage basins and channel networks. Handbook of Applied Hydrology. In: Ven Te Chow (ed.), Section 4-2, Mc Graw-Hill, New York.

Tison J., Giraudel J.L., Coste M., Delmas F. and Park Y-S., 2004. Use of the unsupervised neural network for ecoregional zoning of hydrosystems through diatom communities: case study of AdourGaronne watershed (France). Archiv für Hydrobiologie, 159, 409-422.

Vaughan I.P., Diamond M., Gurnell A.M., Hall K.A., Jenkins A., Milner N.J., Naylor L.A., Sear D.A., Woddward G. and Ormerod S.J., 2009. Integrating ecology with hydromophology: a priority for river science and management. Aquat. Conserv., 19, 113-125.

Verdonschot P.F.M. and Nijboer R.C., 2004. Testing the European stream typology of the Water Framework Directive for macroinvertebrates. Hydrobiologia, 516, 35-54.

Vondracek B., Blann B., Cox C. B., Nerbonne J.F., Mumford K.F., Nerbonne B.A., Sovell L.A. and Zimmermann J.K.H., 2005. Land use, spatial scale, and stream systems: lessons from an agricultural region. Environ. Manage., 36, 775-791. 
Wasson J.-G., Chandesris A., Pella H. and Souchon Y., 2001. Definition of the French hydroecoregions. Methodology for determining reference conditions according to the Framework Directive for water management (Définition des hydroécorégions françaises. Méthodologie de détermination des conditions de référence au sens de la Directive cadre pour la gestion des eaux). Rapport de phase 1. Ministère de l'Aménagement du Territoire et de l'Environnement, Cemagref, France.

Wasson J.-G., Chandesris A., Pella H. and Blanc L., 2002. Les Hydro-écorégions de France métropolitaine. Approche régionale de la typologie des eaux courantes et éléments pour la définition des peuplements de référence d'invertébrés. Cemagref, Lyon, France.

Wiens J.A., 2002. Riverine landscapes: taking landscape ecology into the water. Freshwater Biol., $47501-515$. 


\section{Appendix: Nomenclature of Corine Land Cover.}

Appendice : Nomenclature de Corine Land Cover.

\begin{tabular}{|c|c|c|c|}
\hline Code & Label Level1 - CLC1 & Label Level2 - CLC2 & Label Level3 - CLC3 \\
\hline \begin{tabular}{l|}
111 \\
112 \\
121 \\
122 \\
123 \\
124 \\
131 \\
132 \\
133 \\
141 \\
142
\end{tabular} & Artificial surfaces & $\begin{array}{l}\text { Urban fabric } \\
\text { Industrial, commercial and transport units } \\
\text { Mine, dump and construction sites } \\
\text { Artifiical, non-agricultural vegetated areas }\end{array}$ & $\begin{array}{l}\text { Continuous urban fabric } \\
\text { Discontinuous urban fabric } \\
\text { Industrial or commercial units } \\
\text { Road and rail networks and associated land } \\
\text { Port areas } \\
\text { Airports } \\
\text { Mineral extraction sites } \\
\text { Dump sites } \\
\text { Construction sites } \\
\text { Green urban areas } \\
\text { Sport and leisure facilities }\end{array}$ \\
\hline $\begin{array}{l}211 \\
212 \\
213 \\
221 \\
222 \\
223 \\
231 \\
241 \\
242 \\
243\end{array}$ & Agricultural areas & $\begin{array}{l}\text { Arable land } \\
\text { Permanent crops } \\
\text { Pastures } \\
\text { Heterogeneous agricultural areas }\end{array}$ & $\begin{array}{l}\text { Non-irrigated arable land } \\
\text { Permanently irrigated land } \\
\text { Rice fields } \\
\text { Vineyards } \\
\text { Fruit trees and berry plantations } \\
\text { Olive groves } \\
\text { Pastures } \\
\text { Annual crops associated with permanent crops } \\
\text { Complex cultivation patterns } \\
\text { Land principally occupied by agriculture, } \\
\text { with significant areas of natural vegetation } \\
\text { Agro-forestry areas }\end{array}$ \\
\hline \begin{tabular}{l|}
311 \\
312 \\
313 \\
321 \\
322 \\
323 \\
324 \\
324 \\
331 \\
332 \\
333 \\
334 \\
335 \\
\end{tabular} & Forest and semi-natural areas & $\begin{array}{l}\text { Forests } \\
\text { Scrub and/or herbaceous vegetation } \\
\text { associations } \\
\text { Open spaces with little or no vegetation }\end{array}$ & $\begin{array}{l}\text { Broadleaved forest } \\
\text { Coniferous forest } \\
\text { Mixed forest } \\
\text { Natural grasslands } \\
\text { Moors and heathland } \\
\text { Sclerophyllous vegetation } \\
\text { Transitional woodland-shrub } \\
\text { Beaches, dunes, sands } \\
\text { Bare rocks } \\
\text { Sparsely vegetated areas } \\
\text { Burnt areas } \\
\text { Glaciers and perpetual snow }\end{array}$ \\
\hline $\begin{array}{l}411 \\
412 \\
421 \\
422 \\
423\end{array}$ & W etlands & $\begin{array}{l}\text { Inland wetlands } \\
\text { Maritime wetlands }\end{array}$ & $\begin{array}{l}\text { Inland marshes } \\
\text { Peat bogs } \\
\text { Salt marshes } \\
\text { Salines } \\
\text { Intertidal flats } \\
\end{array}$ \\
\hline $\begin{array}{l}511 \\
512 \\
521 \\
522 \\
523\end{array}$ & W ater bodies & Inland waters & $\begin{array}{l}\text { W ater courses } \\
\text { W ater bodies } \\
\text { Coastal lagoons } \\
\text { Estuaries } \\
\text { Sea and ocean }\end{array}$ \\
\hline
\end{tabular}

